\title{
THE EFFECT OF PERCEIVED BRAND LEADERSHIP TOWARDS CONSUMER SATISFACTION AND REPURCHASE INTENTION ON E-COMMERCE WEBSITE
}

\author{
Bhuanaputra Kadek Widiandita, Giantari I Gusti Ayu Ketut \\ Master's Study Program of Management, Faculty of Economics and Business, \\ University of Udayana, Bali, Indonesia \\ E-mail: bhuanaputra@gmail.com
}

\begin{abstract}
This study tries to show the effect of brand leadership towards consumer satisfaction and repurchase intentions on e-commerce website. It is based on the concepts and theories of all research variables and empirical facts which are then formulated into hypotheses. Data analysis methods used are descriptive analysis and inferential statistical analysis. The tool used in this research is Warp PLS 6.0. The results of this study are positive but not statistically significant on quality perceptions of customer satisfaction and repurchase intentions. The perceived value has a positive but insignificant effect on customer satisfaction and repurchase intentions. The perception of innovation shows a positive and significant effect on customer satisfaction but not statistically significant on repurchase intentions. Perception of popularity has a positive and significant effect on customer satisfaction and repurchase intentions. Businesses who provide e-commerce websites will be better off if they can increase the popularity of their website so that they can provide the pleasure and pride of purchasing on their website. For consumers in this study, we found that promotion of the website itself, popularity of web will increase customer satisfaction and purchasing interest considering users who have known the website. Also, the website becomes a trendsetter that will increase customer confidence to use the website.
\end{abstract}

\section{KEY WORDS}

Perceived brand leadership, customer satisfaction, repurchases intention, E-commerce.

The development of Information Technology provides several conveniences for consumers, including one in the process of buying and selling that can be done via the internet or better known as online shopping transactions or e-commerce (Harahap et al. 2018). Thanks to advances in information technology online shopping offers several more benefits for customers, such as wide selections, low cost, lots of product information available, and the convenience of shopping online because it can be done from various places (Shin et al., 2013; Bulut , 2015; Sastika, 2016).

The number of internet users in Indonesia, which is more than 100 million users, is one of the forces driving e-commerce growth and the average money spent by Indonesian people on e-commerce websites reaches US \$ 228 per person or around Rp 3.19 million per people (katadata.com, 2019). Indonesia is the largest online trade market in Southeast Asia, which is predicted to generate around 2.5 billion dollars in online store customer consumption income and has a possibility of 20 billion dollars by 2022. (Mckinsey, 2018), In general, there are two stages of understanding online consumption behavior. The first stage deals with how to encourage people to buy online and the second stage is to encourage them to make repurchase. These regular customers spend more money on their purchases and generate more profits than new customers (Patel, 2014). Thus, how to retain existing customers to make repurchases is the main concern of e-commerce websites than before (Johnson and Hult, 2008). However, it has been argued that the repurchase rate is the most neglected indicator for e-retailers (Sutto, 2016). In addition, it should be noted that only 32 percent of customers made repurchases on the same e-commerce website in their first year (RJMetrics, 2015).

Indonesia itself has five most popular e-commerce websites in 2018 and 2019, consisting of Tokopedia, Shopee, Lazada, Bukalapak and Blibli, from 2018 to 2019 quarterly, 
Tokopedia itself ranked first, but there was a decline in visits of Tokopedia in the quarter 1 of 2019, which indicates the movement of visitors in the quarter to other online stores on the way Shopee and Bukalapak have increased quite rapidly. Based on a survey of customer satisfaction Tokopedia in Bali conducted to 45 respondents who on average have shopped 2 to 4 times in the last 3 months, there is 1 person who was not satisfied shopping at Tokopedia and 44 people said they were satisfied shopping at Tokopedia out of the 45 respondents there are 4 respondents said they did not want to shop at Tokopedia again and 41 respondents said they wanted to make repurchase at Tokopedia because the website was easy to use, attractive and innovative features, the items sought were available at Tokopedia, the price of the product was cheap, the price was affordable, offered according to product quality, wide array of products, and finally because many of their friends and favorite celebrities use Tokopedia. In line with the survey, factors that influence online consumer repurchase intentions in Tokopedia illustrate the concept of Brand Leadership which includes perceived value (Wu et al., 2014; Lee et al., 2011), quality and functionality of the website (Sharma and Lijuan , 2015; Lee et al., 2011), innovation power (Ghazali et al., 2018) and popularity (Hsiao et al., 2010). These factors mainly explore consumers' perceptions and attributes of certain e-commerce websites. However, there have been several attempts to comprehensively test consumers' perceptions about comparing values, attributes, or features of different e-commerce websites and to investigate their preferences for certain e-commerce websites. The characteristics of the E-Commerce website, are the factors that influence the exploration stage and have a significant influence on purchasing behavior (Mallapragada et al., 2016).

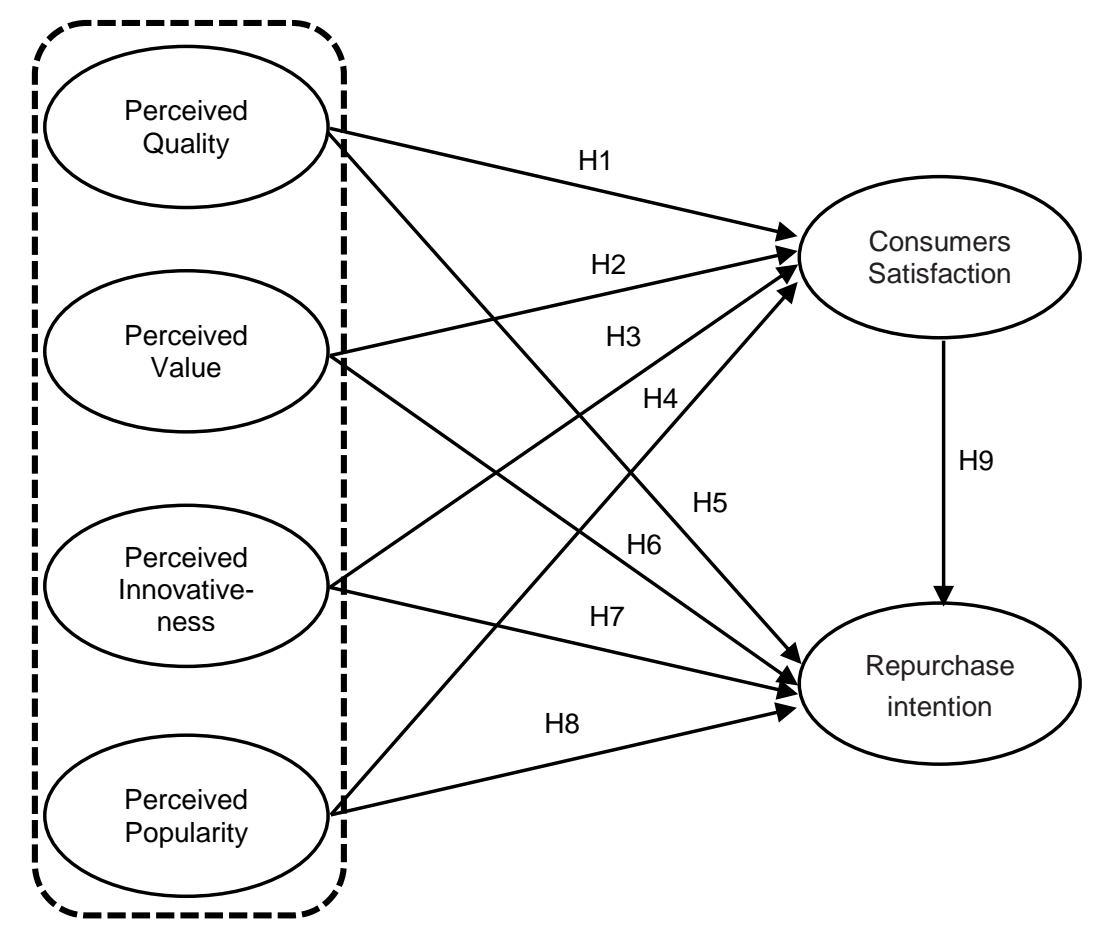

Figure 1 - Conceptual Framework

Previous studies have also found that the extent to which consumers perceive brand leadership tends to influence their decision-making behavior (Chang et al., 2016; Kumar and Jayasimha, 2018; Weisheng and Heetae, 2019). More specifically, consumers can choose a leading brand or service not only because it provides better quality or value, but also because it represents the consumer's self-image (Chang and Ko, 2014). Today, more ecommerce platforms allow consumers to easily browse and compare from various ecommerce platforms before making a purchase. Thus, e-commerce websites that focus on these attributes can create a comparison shopping experience for consumers (Mohseni et al., 2018). Meanwhile, consumers are becoming more aware of the value of e-commerce 
websites and evaluating various attributes and services provided by e-commerce websites (Mallapragada et al., 2016). Supported by developments last year, online trade in Indonesia is still concentrated in big cities on the island of Java, but in 2019, ShopBack.co.id saw an opportunity for e-commerce players to explore cities outside Java. In percentage, internet users in Bali (42.91 percent) are higher than in Java (40.29 percent). Internet penetration is defined as high population access to information via the internet. To enable residents to add knowledge, and skills, and communicate, which indicates the opportunity to expand the online shopping community in Bali. The high internet penetration in this tourism city is triggered by the increasing number of SMEs that make the internet one of the main needs.

Hypotheses:

- H1: Perceived quality has a positive and significant effect on consumers satisfaction;

- H2: Perceived value has a positive and significant effect on consumers satisfaction;

- H3: Perceived innovativeness has a positive and significant effect on consumers satisfaction;

- H4: Perceived popularity has a positive and significant effect on consumers satisfaction;

- H5: Perceived quality has a positive and significant effect on repurchase intentions;

- H6: Perceived value has a positive and significant effect on repurchase intention;

- H7: Perceived innovativeness has a positive and significant effect on repurchase intentions;

- H8: Perceived popularity has a positive and significant effect on repurchase intentions;

- H9: Consumers satisfaction has a positive and significant effect on repurchase intentions.

\section{METHODS OF RESEARCH}

This research uses a quantitative approach that is analyzed associatively. The sampling technique in this study was purposive sampling. Data collection techniques include distributing questionnaires to consumers who have used the Tokopedia website in Bali. The sampling method used in this study is non probability sampling. All research hypotheses were tested using SEM-PLS analysis using Warp-PLS version 6.0. The data obtained will be presented in the discussion and interpretation of the results then conclusions and suggestions are prepared. In this study using 18 indicators so that the number of respondents used for the sample is $18 \times 6=108$ respondents. Determination of the sample of 108 respondents, so for the minimum sample using 108 samples, and in this study will spread 140 questionnaires.

\section{RESULTS AND DISCUSSION}

Based on the results of the three indicators of the fit model, it can be said that the results of this study can be accepted because they meet the criteria for goodness of fit.

The effect of perceived quality on consumers satisfaction. Based on the results of the first hypothesis test found that perceived quality has a positive effect but is not statistically significant to consumers satisfaction. This result means that the higher the consumer's perception of the quality of an e-commerce website, the higher the satisfaction of the consuemen but does not actually provide consumer satisfaction on the e-commerce website, in this case Tokopedia consumers do not feel real satisfaction only with the quality of the site website, although the quality of the website can positively affect consumer satisfaction, but in this case it shows that consumers consider product quality more important than website quality (Luo et al., 2012). Furthermore, return policies and information perceptions are more important in their decision making (Kim et al., 2010).

The effect of perceived value on consumers' satisfaction. Based on the results of the second hypothesis test found that perceived value has a positive effect but is not significant 
to consumers satisfaction. These results mean the higher the consumer's perception of the value of an e-commerce website, the higher the customer satisfaction, but in this study does not significantly provide consumer satisfaction on the e-commerce website, in this case indicates Tokopedia consumers do not feel real there is more value obtained than what consumers pay, in line with the study of Chang et al., (2016) in his research, the value has a positive but not significant effect on service to consumers in private. In research Devaraj et al., (2002) states that nominal values are not enough for consumers to change their shopping behavior. This is only the first step for customers to want to explore the site. Competitive prices, easy navigation, superior search, and high-quality information that can be used will help keep customer transaction costs low, although it can satisfy consumers, businesses must realize that to get customer satisfaction must be more convincing consumers.

Table 1 - Goodness of Fit

\begin{tabular}{lllll}
\hline \multicolumn{1}{c}{ Model fit } & index & $p$-value & criteria & notes \\
\hline Average path coefficient (APC) & 0.210 & $\mathrm{P}<0.005$ & $\mathrm{P}<0.050$ & Accepted \\
\hline Average R-Squared (ARS) & 0.633 & $\mathrm{P}<0.001$ & $\mathrm{P}<0.050$ & Accepted \\
\hline Average Block Variance Inflation Factor (AVIF) & 1.870 & & $<5$ & Accepted \\
\hline
\end{tabular}

Source: Processed From Data, 2019.

Table 2 - Coefficient relationship between variables

\begin{tabular}{lllll}
\hline & & & $P a t h$ coefficients & $P$ values \\
\hline Perceived Quality & $--->$ & Consumers Satisfaction & 0,118 & 0,102 \\
\hline Perceived Value & $-->$ & Consumers Satisfaction & 0,129 & 0,082 \\
\hline Perceived Innovativeness & $--->$ & Consumers Satisfaction & 0,389 & $<0.001$ \\
\hline Perceived Popularity & $-->$ & Consumers Satisfaction & 0,272 & 0,001 \\
\hline Perceived Quality & $-->$ & Repurchase Intention & 0,021 & 0,411 \\
\hline Perceived Value & $--->$ & Repurchase Intention & 0,095 & 0,155 \\
\hline Perceived Innovativeness & $-->$ & Repurchase Intention & 0,031 & 0,371 \\
\hline Perceived Popularity & $--->$ & Repurchase Intention & 0,380 & $<0,001$ \\
\hline Consumers Satisfaction & $-->$ & Repurchase Intention & 0,457 & $<0,001$ \\
\hline
\end{tabular}

Source: Processed From Data, 2019.

The effect of perceived innovativeness on consumers' satisfaction. Based on the results of the third hypothesis test found that perceived Innovativeness has a positive and significant effect on consumers satisfaction. These results mean the higher the consumer's perception of an e-commerce website innovation, the higher the satisfaction that consumers will feel when using the e-commerce website for shopping. In line with the research of chang and ko (2018) and Wu et al., (2019) that innovation has a positive and significant influence on customer satisfaction, Crawford and Di Benedetto (2003) note that innovativeness is a factor that reflects the level of brand openness towards new ideas. From a consumer perspective, satisfaction is achieved when innovative elements in the service or product are considered valuable. Consumers expect the concepts adopted by the brand will continue to develop according to trends. When a brand is constantly known for its innovation, customer satisfaction will be rooted in being part of a trend-determining brand

The effect of perceived popularity on consumers' satisfaction. Based on the results of the fourth hypothesis test found that perceived popularity has a positive and significant effect on consumers satisfaction. These results mean the higher the consumer's perception of the popularity of e-commerce websites, the higher the satisfaction will be felt by consumers when using the e-commerce website for shopping. The popularity of a leading brand has the potential to trigger consumer deviation from its true value and lead them to benefits such as self-esteem. Kim and Lennon (2013) note that consumers have high opinions about leading brands even when they are not proven to provide high quality products, consumers will still feel satisfied.

The effect of perceived quality on repurchase intention. Based on the results of the fifth hypothesis test found that perceived quality has a positive effect but is not significant to 
repurchase intention. These results mean the higher the consumer's perception of the quality of an e-commerce website, the higher the desire to repurchase but does not significantly affect the desire to repurchase on the e-commerce website, in this case the Tokopedia consumer tendency in Bali considers a return policy and information perception is more important in their decision making (Kim et al., 2010). in line with what was stated by Cronin \& Taylor (1992) that a high quality service does not always affect the high interest of consumers to buy back.

The effect of perceived value on repurchase intention. Based on the results of the sixth hypothesis test found that the perceived value has a positive effect but is not significant to the repurchase intention. These results mean the higher the consumer's perception of the value of an e-commerce website, the higher the desire to repurchase but does not significantly affect the desire to repurchase on the e-commerce website, in this case the brand manager needs to arrange the purchasing benefits that make it more higher than the number of sacrifices made by consumers (Kuo et al., 2009) and this study indicates that consumers of Tokopedia in Bali do not yet know the value of more products purchased from the Tokopedia website.

The effect of perceived innovativeness on repurchase intention. Based on the results of the seventh hypothesis test, it is found that perceived innovativeness has a positive but not significant effect on repurchase intention. These results mean the higher the consumer's perception of the innovation of an e-commerce website, the higher the desire to repurchase but does not significantly affect the desire to repurchase on the e-commerce website, in line with research by Wu et al., (2019) which stated no significant relationship was found between innovation and repurchase intention, because consumers would observe and evaluate the level of brand innovation, which could ultimately influence their buying behavior. Therefore, service providers need to ensure that their unique characteristics are stable over time to maintain the image of innovation and concentrate their efforts on developing creative and unconventional ideas (Chang and Ko, 2014; Chang et al., 2016). When a brand is constantly known for its innovativeness, customer satisfaction will be rooted in being part of a trenddetermining brand, which in turn encourages repurchase intentions.

The effect of perceived popularity on repurchase intention. Based on the eighth hypothesis test results found that perceived popularity has a positive and significant effect on repurchase intention. These results mean the higher the consumer's perception of the popularity of e-commerce websites, the higher the desire to repurchase consumers when using the e-commerce website for shopping. In line with the research of Wu et al., (2019) and Chang and Ko (2014). The results of the study show that social recognition of brands and positive rewards encourage them to buy popular products (Zhu and Zhang, 2010; Chang and Ko, 2014). Kim and Lennon (2013) note that consumers have high opinions about leading brands even when they are not proven to provide high quality products. Online word of mouth or online consumer reviews can be used to increase and maintain popularity, which can build trust and reduce perceived risk (Park and Kim, 2008; Hsiao et al., 2010) that keep consumers buying products on the website.

The effect of consumers' satisfaction on repurchase intention. Based on the ninth hypothesis test results found that consumers satisfaction has a positive and significant effect on repurchase intention. These results mean the higher the customer satisfaction with the ecommerce website, the higher the desire to repurchase consumers when using the ecommerce website for shopping. In line with the research of Wu et al., (2019) and Chang and Ko (2014). In the context of online shopping, consumer satisfaction is generated by positive shopping experiences on e-commerce websites. a positive psychological state determines the future buying behavior of consumers on e-commerce websites. In line with the results of previous studies in the context of online shopping (Carlson and O'cass, 2010; Kim, 2012; Cao et al., 2018; Kassim and Abdullah, 2010) and with expectation confirmation theory abbreviated as ECT, which identifies satisfaction as a critical predictor of continuation of consumers' intention to buy (Kim et al., 2009; Oliver, 1980). Although ECT has been applied in various disciplines, such as tourism (Escobar-Rodríguez and Bonsón-Fernández, 2017), e-learning (Lee, 2010) and cellular data services (eg Kim, 2010), there have been several 
attempts to explain consumer behavior use ECT in the e-commerce settings uttered by Wu et al., (2019) and applied in areas with different consumer behavior.

The scope of this research is only for Tokopedia consumers in the City of Denpasar, so the results of the study cannot be generalized to consumers of e-commerce sites in other regions. Limitations on the number of respondents, should in the future this study use the entire consumer in e-commerce itself. This research only discusses e-commerce in Indonesia, not e-commerce outside Indonesia. This research is only conducted in a certain time point (cross section) while the environment changes (dynamic) at any time, so this research is important to do again in the future.

\section{CONCLUSION AND SUGGESTIONS}

Based on the results of the discussion of research that has been done, it can be concluded that perceived quality has a positive effect and yet is not significant to consumers satisfaction. Perceived value has a positive and but not significant effect on consumers satisfaction. Perceived innovativeness has a positive and significant effect on consumers satisfaction. Perceived popularity has a positive and significant effect on consumers satisfaction. Perceived value has a positive and but not significant effect on repurchase intention. Perceived innovativeness has a positive and but not significant effect on repurchase intention. Perceived popularity has a positive and significant effect on repurchase intention. Perceived consumers satisfaction has a positive and significant effect on repurchase intention. The advice that can be delivered is that business people who provide e-commerce websites will be better if they can improve the innovation and popularity of their websites so that they can provide the pleasure and pride of shopping on their websites. Although in this study quality and value do not significantly affect, but this is simply because consumers cannot compare the quality of each website because the longer the quality tends to be the same and the value, the website should increase information to customers that the products purchased on their website have value more than the price paid. Consumers in this study, more influenced by the popularity of the website itself, the more popular the website, customer satisfaction and desire to buy will increase due to the number of users who know the website, and the website becomes a trendsetter that will increase customer confidence to use the website the. Suggestions for future research are to consider using conducting research in different places and also broadening the scope of the study area and targeting more respondents and focusing on specific target markets. Research should also be conducted on several different types of e-commerce websites such as B2B so that they can be compared because each website has its own characteristics and advantages.

\section{REFERENCES}

1. Bulut, A. Z. 2015. Determinants of Repurchase Intention in Online Shopping: a Turkish Consumer's Perspective. International Journal of Business and Social Science, Vol. 6, No. 10 , pp. 55-63.

2. Cao, Y., H. Ajjan, and P. Hong. 2018. Post-purchase shipping and customer service experiences in online shopping and their impact on customer satisfaction: an empirical study with comparison. Asia Pacific Journal of Marketing and Logistics, Vol. 30, No. 2, pp. 400-416.

3. Carlson, J., and A. O'cass. 2010. Exploring the relationships between e-service quality, satisfaction, attitudes and behaviours in content-driven e-service web sites, Journal of Services Marketing, Vol. 24 No. 2, pp. 112-127.

4. Chang, Y., and Y.J. Ko. 2014. The brand leadership: scale development and validation. Journal of Brand Management, Vol. 21, No. 1, pp. 63-80.

5. Chang, Y., Y.J. Ko, and W.L. Leite. 2016. The effect of perceived brand leadership on luxury service WOM, Journal of Services Marketing, Vol. 30, No. 6, pp. 659-671.

6. Chiu, Weisheng., and Cho Heetae. 2019. E-Commerce brand: The effect of perceived brand leadership on consumers' satisfaction and repurchase intention on e-commerce 
websites. Asia Pacific Journal of Marketing and Logistics. (online), (https://www.researchgate.net/publication/333003743)

7. Cronin, JJ., And S.A. Taylor. 1992. Measuring service quality: a reexamination and extension. Journal of Marketing, Vol. 56.

8. Devaraj, S., M. Fan, and R. Kohli. 2002. Antecedents of B2C channel satisfaction and preference: validating e-commerce metrics. Information Systems Research, Vol. 13, No. 3, pp. 316-333.

9. Escobar-Rodríguez, T. and R. Bonsón Fernández. 2017. Analysing online purchase intention in Spain: fashion E-Commerce. Information Systems and e-Business Management, Vol. 15, No. 3, pp. 599-622.

10. Ghazali, E.M., D.S. Mutum, J.H. Chong, and B. Nguyen. 2018. Do consumers want mobile commerce? A closer look at M-shopping and technology adoption in Malaysia. Asia Pacific Journal of Marketing and Logistics, Vol.30, No. 4, pp. 1064-1086.

11. Hsiao, K.L., J.C.C. Lin, X.Y. Wang, H.P. Lu, and H. Yu. 2010. Antecedents and consequences of trust in online product recommendations: an empirical study in social shopping. Online Information Review, Vol. 34, No. 6, pp. 935-953.

12. Shin, Jae., Ki Chung, Jae Oh, and Chang Won Lee. 2013. The effect of site quality on repurchase intention in Internet shopping through mediating variables: The case of university students in South Korea. International Journal of Information Management, Vol. 33, No. 3, pp. 453-463.

13. Johnson, C., and P. Hult, and B. McGowan. 2008. Web Buyers and their Expectations Grow up: Experienced Web Buyers are becoming the New Mainstream. Forrest Research. (Online) (https://www.forrester.com/research/PDF/0,5110,45462,00.pdf).

14. Kim, D.J. 2012. An investigation of the effect of online consumer trust on expectation, satisfaction, and post-expectation. Information Systems and E-Business Management, Vol. 10, No. 2, pp. 219-240.

15. Kim, D.J., D.L. Ferrin, and H.R. Rao. 2009. Trust and satisfaction, two stepping stones for successful e-commerce relationships: a longitudinal exploration. Information Systems Research, Vol. 20, No. 2, pp. 237-257.

16. Kim, J. and S.J. Lennon. 2013. Effects of reputation and website quality on online consumers emotion, perceived risk and purchase intention: based on the stimulus organism response model. Journal of Research in Interactive Marketing, Vol. 7, No. 1, pp. 33-56.

17. Kim, J.U., W.J. Kim, and S.C. Park. 2010. Consumer perceptions on web advertisements and motivation factors to purchase in the online shopping. Computers in Human Behavior, Vol. 26, No. 5, pp. 1208-1222.

18. Kim, K.C. 1995. Brand popularity and country image in global competition: managerial implications. Journal of Product \& Brand Management, Vol. 4 No. 5, pp. 21-33.

19. Kim, M.-J., C.K. Lee, and N. Chung. 2013. Investigating the role of trust and gender in online tourism shopping in South Korea. Journal of Hospitality \& Tourism Research, Vol. 37, No. 3, pp. 377-401.

20. Kumar, S.M. and K. Jayasimha. 2019. Brand verbs: brand synonymity and brand leadership. Journal of Brand Management, Vol. 26, No. 2, pp. 110-125.

21. Langerak, Fred and Erik Hultink. 2006. The impact of product innovativeness on the link between development speed and new product profitability. Journal of Product Innovation Management, Vol. 23, No.3, pp 203 - 214.

22. Lee, C.H., Uchenna, C.E. and Nelson, N.O. 2011. Analyzing key determinants of online repurchase intentions. Asia Pacific Journal of Marketing and Logistics, Vol. 23 No. 2, pp. 200-221.

23. Luo, J., Ba, S. and Zhang, H. 2012. The effectiveness of online shopping characteristics and well- designed websites on satisfaction. MIS Quarterly, Vol. 36 No. 4, pp. 1131-1144.

24. Mallapragada, G., Chandukala, S.R. and Liu, Q. 2016. Exploring the effects of 'what' (product) and 'where' (website) characteristics on online shopping behavior. Journal of Marketing, Vol. 80 No. 2, pp. 21-38. 
25. Mckinsey. 2018. The Digital Archipelago: How Online Commerce Is Driving Indonesia's Economic Development. ASIA: Mckinsey

26. Mohseni, S., Jayashree, S., Rezaei, S., Kasim, A. and Okumus, F. 2018. Attracting tourists to travel companies' websites: the structural relationship between website brand, personal value, shopping experience, perceived risk and purchase intention. Current Issues in Tourism, Vol. 21 No. 6, pp. 616-645.

27. Olarte-Pascual, C., Pelegrín-Borondo, J. and Reinares-Lara, E. 2016. Cognitive-affective model of acceptance of model phone advertising. E\&M Economics and Management, Vol. 19 No. 4, pp. 134-148.

28. Oliver, R.L. 1980. A cognitive model of the antecedents and consequences of satisfaction decisions. Journal of Marketing Research, Vol. 17 No. 4, pp. 460-469.

29. Patel, N. 2014. How to make more money without making more sales. (Online) pada www.forbes.com/sites/neilpatel/2014/11/17/how-to-make-more-money-without-makingmore-sales/\#742a69fe2 3aa (di akses 20 September 2019).

30. Rahyuda, K. 2016. Metode Penelitian Bisnis. Denpasar: Udayana University Press

31. RJMetrics. 2015. 2015 benchmark report series ecommerce buyer behavior di https://rjmetrics.com/resources/reports/ecommerce-buyer-behavior/ (di akses 20 September).

32. Sastika, W. 2016. Analisis Pengaruh Kualitas Website (WEBQUAL 4.0) Terhadap Keputusan Pembelian Pada Website E-Commerce TRAVELOKA Studi Kasus: Pengguna Traveloka di Kota Bandung Tahun 2015. Seminar Nasional Teknologi Informasi dan Komunikasi

33. Sharma, G. and Lijuan, W. 2015. The effects of online service quality of e-commerce websites on user satisfaction. The Electronic Library, Vol. 33 No. 3, pp. 468-485.

34. Sutto, M. 2016. Repurchase rate the most overlooked e-commerce KPI di https://medium.com/@matsutton/repurchase-rate-the-most-overlooked-ecommerce-kpi337bccde184b (di akses 20 September 2019).

35. Zhang, Y., Fang, Y., Wei, K.-K., Ramsey, E., Mccole, P. and Chen, H. 2011. Repurchase intention in B2C e-commerce a relationship quality perspective. Information \& Management, Vol. 48 No. 6, pp. 192-200.

36. Zhu, F. and Zhang, X. 2010. Impact of online consumer reviews on sales: the moderating role of product and consumer characteristics, Journal of Marketing, Vol. 74 No. 2, pp. 133-148. 